\title{
University Students' Perceptions and Attitudes about Freedom of Claiming Educational Rights: Ege University ${ }^{i}$
}

\author{
Recep Cengiz Akçay ", Püren Akçay Üzüm \\ Faculty of Education, Istanbul Aydın University, Turkey
}

Copyright $\subseteq 2016$ by authors, all rights reserved. Authors agree that this article remains permanently open access under the terms of the Creative Commons Attribution License 4.0 International License

\begin{abstract}
The main purpose of this study is to define perceptions and attitudes of university students about freedom of claiming their educational rights. Research was designed within the framework of phenomenology which is one of the qualitative research designs. The study was conducted with 10 students from EGE University in the academic year of 2014-2015. The participants of the study were determined with the purposeful sampling method in two phases. In this research, students were interviewed in accordance with semi-structured interview technique. Data were analyzed with induction analyzing method and the findings of research were debated by comparing with literature. According to the research findings, it is observed that students' attitudes of claiming right are not occurred. Also students' consciousness of claiming right seems to be quite inadequate.
\end{abstract}

Keywords Freedom of Claiming Rights, Right to Education, Fundamental Rights and Freedoms

\section{Introduction}

Every citizen has rights and responsibility to claim for their rights. Ways of claiming rights provide the inspection of fulfilling the executives' obligations to the students as a citizen and all interested citizens. There are lots of things you can do when the right to receive education violated through omission or violated as a result of an action.

The main purpose of this study is to define the perceptions and attitudes of university students about freedom of claiming their educational rights. In accordance with this purpose, it has been sought answers to the following questions:

1. What is the degree of proficiency of students about conceptual framework of freedom of claiming right to education?

2. What are the students' perceptions and attitudes about process of claiming right?

3. How much information students have about remedies?

4. What are the students' perceptions and attitudes about obstacles in the process of claiming right?

There are two important limitations of this study. One of these limitations is about scope of the research. In this research, only individual ways of claiming the right to education in national and international law have been discussed. And ways of claiming right such as acting with organization, cooperating with media, using the right to assembly and demonstration, making joint efforts with non-governmental organizations were excluded from the research.

Other limitation of the research is about study group. Convenience sampling method was used at the first phase of determining study group. The study was carried out with students from Ege University. Ege University students are the first available primary data source will be used for the research without additional requirements. This sampling method involves getting participants wherever you can find them and typically wherever is convenient. According to such inferences, population of university and location of university are the most convenient facts about research's sample. Because of this limitation, we can't generalize the study for all university students in Turkey. Research samples are described in detail for Ege University students.

\subsection{Concepts of 'Right' and 'Freedom'}

The concept of 'right' means 'legally protected benefit, justice; authority given to the individual; freedom of behavior, authority of acquire and propounding ownership; the privilege provided with law (Yılmaz, 1996 \& Şafak, 1998). The concept of 'freedom' means that to act individual as without being under any pressure, without harm to others, within the limits of the law (Y1lmaz, 1996 \& Ovac1k, 2003). Freedom is a right that individuals born with and this right is indispensable and inalienable. And rights are authorities that given individuals to create their freedoms.

\subsection{Fundamental Rights and Freedoms}


Georg Jellinek has developed a well-known classification of subjective rights in relation to particular "statuses" thus he distinguished status passivus (which entails general subjection to the state), status negativus (which assures rights of protection against the state), status positivus (which grants rights to positive actions by the state), and status activus (which guarantees rights of political participation, especially voting). Restriction of fundamental rights was regulated by Constitution (Kapani, 1981 \& Sabuncu, 2014).

According to Constitution; Article 13: 'Fundamental rights and freedoms may be restricted by law, in conformity with the letter and spirit of the Constitution, with the aim of safeguarding the indivisible integrity of the State with its territory and nation, national sovereignty, the Republic, national security, public order, general peace, the public interest public morals and public health, and also for specific reasons set forth in the relevant Articles of the Constitution.' Frame of grounds for restrictions of fundamental rights and freedoms are also specified in the Constitution. According to Article 13 paragraph 2: 'General and specific grounds for restrictions of fundamental rights and freedoms may not conflict with the requirements of the democratic order of society and may not be imposed for any purpose other than those for which they are prescribed. The general grounds for restriction stipulated in this Article apply to all fundamental rights and freedoms.'

\subsection{Human Rights and right to Education}

Human rights are rights inherent to all human beings, whatever our nationality, place of residence, sex, national or ethnic origin, color, religion, language, or any other status. We are all equally entitled to our human rights without discrimination. These rights are all interrelated, interdependent and indivisible. The right to receive education is a universal entitlement to education, recognized in the International Covenant on Economic, Social and Cultural Rights as a human right (Kaboğlu, 1999 \& Tezcan, Erdem \& Bayrakdar, 2002).

\subsection{Concept of 'Freedom of Claiming Right'}

The concept of 'freedom of claiming right' is generally inferred as prerequisite, and procedural safeguards of the rights recognized by positive law (Kaboğlu, 1999, s.9). Ways of claiming right to education are performed in two ways, namely national and international.

\subsection{Ways of Claiming Right to Education}

In this research, only the national and international ways of claiming right to education were investigated.

\subsubsection{National Ways of Claiming Right to Education}

Administrative remedies and judicial remedies of claiming rights were investigated in this section.

\subsubsection{Administrative Remedies}

The most important of the remedies of the right to education are administrative ones. Administrative remedies of the right to education are application to administrative authorities and administrative cases.

- Application to administrative authorities: Application to administrative authorities can be grouped under three headings. The first one is the right to petition. According to Constitution Article 74; 'Citizens have the right to apply in writing to the competent authorities and to the Grand National Assembly of Turkey with regard to requests and complaints concerning themselves or the public. The result of the application concerning himself shall be made known to the petitioner in writing. The form of exercising this right is determined by law.' Also Law No. 3071 (Law on the Use of Right to Petition) regulates 1ssues such as how to use the right of petition and what information the petition should contain. Commissions and boards that can be referenced with a petition are Grand National Assembly of Turkey Petition Committee, Grand National Assembly of Turkey Human Rights Investigation Commission, Prime Ministry Human Rights Presidency, Provincial Human Rights Boards, Ministry of Health General Directorate of Curative Services Patient Rights Branch, Information Assessment Board (Gözübüyük \& Tan, 2014).

The second way of application to the administrative authorities is to use the right to information. According to Law No. 4982 (Right to Information Law), everyone has the right to request information and documents from the authorities. Applications are made to the institution which has information or document that you want (Gözübüyük \& Tan, 2014).

The third way of application to the administrative authorities is to make application when it is an obligation to suit in judicial process. You can make application to administrative authorities before administrative cases, in case that constitutes a prerequisite for recourse to administrative authorities. Everyone can apply to administrative authorities who suffered by a decision, an action or a proceeding taken by the administrative authorities. These applies can be made for the removal of administrative proceedings, withdrawal of the administrative process, changing the administrative process or making a new administrative procedures (Gözübüyük \& Tan, 2014).

- Administrative cases: There are three types of courts in administrative cases. Cases can be open in administration courts if infringement does not fall under the remit of the Supreme Court. The objection authorithy of administration courts is Regional Administrative Court. Supreme Court acts as the court of first instance for the cancellation of the general regulatory process. There are four options depending 
on preferences about administrative process that relates to a violation of the right to education.

Firstly, action of annulment can be suited. After decision of the court, appeal and objection ways can be used. According to the Supreme Court' or Regional Administrative Court' decisions way of administrative action for damages can be used. Secondly, Way of administrative action for damages can be used directly after the conclusion of annulment action. Thirdly, administrative action for damages can be used directly. And finally administrative action for damages and action of annulment can be suited together (Gözübüyük \& Tan, 2014).

Administrative adjudication ways are action of annulment, administrative action for damages, execution, appeal and way of correction the decisions of Supreme Court. Action of annulment is used to cancel the action in case the action is contrary to law with its authority, form, reason, subject or purpose. Administrative action for damages is used for the fulfillment of the right violated by administrative actions, transactions and contracts; and for stopping the intervention; restore or compensation the damages. One of the parties of case must have made request in regard for granting a decision of execution, nevertheless administration court may accept this request of execution. Supreme Courts are authorized with appeal of the final decisions of the administrative courts. Decisions given by the Supreme Court on appeal and decisions given by regional administrative courts on objection can be corrected with the way of correction decisions. The way of correction the courts decisions is important therefore being the last point of domestic remedies. Applications to the European Court of Human Rights can be made after consume of domestic remedies (Gözübüyük \& Tan, 2014).

\subsubsection{Judicial Remedies}

In order to apply to the courts in the judicial system and to claim liability, the right to education needs to be violated by individuals but does not have a criminal nature. In order to apply to the penalty courts in the judicial system is a mandatory if violation of the right to education is concerned with arrangements under the Turkish Penal Code and has a criminal nature. Companion cases can be open in civil courts if there is material or moral damage. Criminal cases can be open in criminal courts if criminal action has criminal elements (Toros \& Feyzioğlu, 2014).

\subsubsection{International Ways of Claiming Right to Education}

Remedies in national law must be completed before applying to the international remedy ways. Every covenant which contains provisions on the right to education offers various remedies about violation of the right to education.

\subsubsection{Individual complaints}

Using the individual complaint procedures, individuals can apply directly to the organ responsible for the supervision of the contract when a right held under international agreements is violated. The organs that can be made complaints in case of violation of the right to education are:

- Human Rights Committee at International Covenant on Civil and Political Rights

- Committee on the Elimination of Discrimination Against Women at Elimination of All Forms of Discrimination Against Women Convention

- European Court of Human Rights at European Convention on Human Rights

There is no international organization could enforce their decisions of committees to states. But in practice, they are often seen to comply with the Committees' decisions. The basic reason of this is international prestige of states (Tezcan, Erdem, Sancakdar \& Önok, 2010).

\subsubsection{Public complaints}

Public complaints can be made according to Revised European Social Charter which regulates the right to education. The state in violation of the social condition provides periodic reports to European Committee of Social Rights. The state informs the committee about what state did to remedy the violation (Tezcan, Erdem, Sancakdar \& Önok, 2010).

\subsection{Political and Educational Contexts of Turkey}

In Turkey it is hard to say that right to education and freedom is in accordance with adopted standards of international human rights and related documents.

Turkey has confirmed international agreements regarding right to education too late or has confirmed by putting some reservations that touching the essence of right to education.

For example, International Covenant on Economic, Social and Cultural Rights (ICESCR) has given the most widescreen coverage to right to education in international human rights law. Turkey signed this Covenant in 2000, 34 years after announcement and has been a party by the consent of Parliament in 2003. Similarly, Turkey has confirmed European Social Charter and Convention on the Rights of the Child by putting some reservations that touching the essence of right to education.

The Constitution of 1982 has imposed a three stage limitation to educational right and freedom. First limitation of educational right and freedom is applies to all fundamental rights and freedoms. These limitations are stated at Article $13^{\text {th }}$ of Constitution and it is named 'General Restrictions'.

The second limitation of educational right and freedom is named 'Special Restrictions' which has laid out in the articles of educational rights and freedoms. According to article 42 '...Training and education shall be conducted along the lines of the principles and reforms of Atatürk, on the basis of contemporary science and educational methods, under the supervision and control of the state...The freedom of training and education does not relieve the individual from 
loyalty to the Constitution.... No language other than Turkish shall be taught as a mother tongue to Turkish citizens at any institutions of training or education. Foreign languages to be taught in institutions of training and education and the rules to be followed by schools conducting training and education in a foreign language shall be determined by law...'

The third limitation of educational right and freedom is the prohibition of abuse of fundamental rights and freedoms (Article 14).

\section{Method}

\subsection{Type of Research}

The present study was carried out within the framework of phenomenology (Patton, 2002; Yıldırım \& Şimşek, 2008). Phenomenology focuses on the facts that we are aware however we don't have a thorough and detailed understanding. In this type of research, data sources are individuals or groups who lives and who can reflect and externalize the focused fact of research.

\subsection{Study Group}

The study was carried out with 10 students from EGE University in the academic year of 2014-2015. The participants of the study were determined with the purposeful sampling method in three phases.

At the first phase of determining study group, convenience sampling method was used. Convenience sampling is a type of sampling where the first available primary data source will be used for the research without additional requirements. In other words, this sampling method involves getting participants wherever you can find them and typically wherever is convenient (Bailey, 1987; akt. Balc1, 2005).

At the second phase of determining study group, criterion sampling method was used. Criterion sampling method allows determining the participants who have certain characteristics and who meet certain criteria (Gay, Mills, \& Airasian, 2006).

Violation of Right to education can be by two ways. First way is to make actions and processes against conventions and international laws. And the second way of violation of right to education is to negligence.

In this study, criteria of study group were determined in line with this consideration. According to this, 10 students who meet the criteria were determined.

At the third phase of shaping the research study group, students were determined with the opposite situation purposeful sampling method (Yıldırım \& Şimşek, 2008). Opposite situation sampling method creates study group with opposite conditions or examples related to the main problem of research. According to opposite situation sampling, method determined with 5 students who have an experience of claiming right and 5 students who don't have any experience of claiming right.
Table 1. Characteristics of Study Group

\begin{tabular}{|c|c|c|c|c|}
\hline $\begin{array}{l}\text { Type of } \\
\text { Graduated } \\
\text { School }\end{array}$ & $\begin{array}{l}\text { Type } \\
\text { of } \\
\text { School }\end{array}$ & $\begin{array}{c}\text { Number } \\
\text { of Years } \\
\text { at } \\
\text { University }\end{array}$ & $\begin{array}{c}\text { Subscribed } \\
\text { Non-Govermental } \\
\text { Organizations }\end{array}$ & $\begin{array}{l}\text { Law } \\
\text { courses } \\
\text { throughout } \\
\text { education } \\
\text { period }\end{array}$ \\
\hline $\begin{array}{l}\text { Anatolian } \\
\text { High } \\
\text { School }\end{array}$ & Faculty & 1 & - & $\begin{array}{c}\text { Introduction } \\
\text { to Law } \\
\text { Course at } \\
\text { University }\end{array}$ \\
\hline $\begin{array}{l}\text { Anatolian } \\
\text { High } \\
\text { School }\end{array}$ & Faculty & 4 & $\begin{array}{c}\text { Kemalist Thought } \\
\text { Community } \\
\text { Turkey Youth } \\
\text { Union } \\
\end{array}$ & ( \\
\hline $\begin{array}{l}\text { Anatolian } \\
\text { High } \\
\text { School }\end{array}$ & Faculty & 1 & $\begin{array}{c}\text { Kemalist Thought } \\
\text { Community } \\
\text { Turkey Youth } \\
\text { Union } \\
\end{array}$ & $\begin{array}{c}\text { Democracy } \\
\text { course at } \\
\text { High } \\
\text { School } \\
\end{array}$ \\
\hline $\begin{array}{l}\text { Anatolian } \\
\text { High } \\
\text { School }\end{array}$ & Faculty & 1 & $\begin{array}{c}\text { Kemalist Thought } \\
\text { Community } \\
\text { Turkey Youth } \\
\text { Union } \\
\end{array}$ & $\begin{array}{c}\text { Introduction } \\
\text { to Law } \\
\text { Course at } \\
\text { university }\end{array}$ \\
\hline $\begin{array}{l}\text { Anatolian } \\
\text { High } \\
\text { School }\end{array}$ & Faculty & 4 & $\begin{array}{l}\text { Kemalist Thought } \\
\text { Community } \\
\text { Turkey Youth } \\
\text { Union }\end{array}$ & $\begin{array}{l}\text { Introduction } \\
\text { to Law } \\
\text { Course at } \\
\text { Open } \\
\text { University }\end{array}$ \\
\hline $\begin{array}{l}\text { Anatolian } \\
\text { High } \\
\text { School }\end{array}$ & Faculty & 6 & $\begin{array}{c}\text { Kemalist Thought } \\
\text { Community } \\
\text { Turkey Youth } \\
\text { Union } \\
\end{array}$ & $\begin{array}{c}\text { Admiralty } \\
\text { Law }\end{array}$ \\
\hline $\begin{array}{l}\text { Anatolian } \\
\text { High } \\
\text { School }\end{array}$ & Faculty & 6 & $\begin{array}{c}\text { Kemalist Thought } \\
\text { Community } \\
\text { Turkey Youth } \\
\text { Union } \\
\end{array}$ & - \\
\hline $\begin{array}{l}\text { High } \\
\text { School }\end{array}$ & Faculty & 4 & $\begin{array}{c}\text { Kemalist Thought } \\
\text { Community } \\
\text { Turkey Youth } \\
\text { Union }\end{array}$ & - \\
\hline $\begin{array}{l}\text { High } \\
\text { School }\end{array}$ & Faculty & 1 & $\begin{array}{c}\text { Kemalist Thought } \\
\text { Community } \\
\text { Turkey Youth } \\
\text { Union } \\
\end{array}$ & $\begin{array}{c}\text { Introduction } \\
\text { to Law } \\
\text { Course at } \\
\text { University }\end{array}$ \\
\hline $\begin{array}{l}\text { Private } \\
\text { Anatolian } \\
\text { High } \\
\text { School } \\
\end{array}$ & Faculty & 1 & $\begin{array}{c}\text { Kemalist Thought } \\
\text { Community } \\
\text { Turkey Youth } \\
\text { Union } \\
\end{array}$ & - \\
\hline
\end{tabular}

According to Table 1, seven of the students graduated from Anatolian High School. All of the students participating to the research are studying at faculty. Nine of the students are members of the Kemalist Thought Community. At the same time four of the students are members of Turkey Youth Society.

When Table 1 is analyzed, it is observed that 6 of participants have taken law related courses. Only 1 of students has taken into this lesson at high school, other ones have taken these lessons at university.

\subsection{Data Collection Tools}

Data of the research were obtained by semi-structured interview technique that is conducted with students in the working group (Yıldırım \& Şimşek, 2008). Semi-structured 
interview technique was found adequate for this research because its properties of flexibility to adapt to changing conditions, instant feedback, detailed information, correcting misunderstandings and individuality of the answers. Semi-structured interview form has been developed by researcher. Firstly, the pilot interview made with a student outside of the working group. Interview form has been prepared in line with the findings of this interview. Interview form was examined by experts. Interview form was finalized after the necessary corrections. There are totally 15 questions in the interview form. Voice recorder was used on the permission received from students during interviews. Each interview lasted an average of 20 minutes.

\subsection{Data Analysis}

Inductive analysis method, one of content analysis methods, was used for analysis of the data collected in this study (Yıldırım \& Şimşek, 2008). For the inductive analysis, the data were classified with respect to their types to prepare for the analysis. Within the scope of this classification, the data were transcribed and organized. Reducing bias is aimed at study with giving frequencies of result of data analysis about perceptions and attitudes of university students about freedom of claiming their rights.

Internal validity is achieved by quoting verbatim from students' views which codes and themes were obtained from, referencing the participants' confirmation, making consistent predictions and generalizations and supporting research with researcher diary.

Working group of research was presented in details in scope of external validity. Researcher carried out data variation and conversion raw data to themes (Fraenkel \& Wallen, 2003) for research reliability.

Data variation, feedback from colleagues, confirmations of participants, detailed description of the context ways are used for persuasiveness of research (Lincoln \& Guba, 1985). In the scope of data variation, researcher' diaries, interview data and informal interviews were used. During this process, participants' confirmations were consulted in cases of not fully understood views or cannot be thematized views. Experts have followed the research process and have contributed to create the interview form and data analysis.

\section{Findings}

In this section, themes and sub-themes were examined that emerged by the analysis of the data which were collected to determine perceptions and attitudes about freedom of claiming right of university students.

\subsection{Proficiency of Students about Conceptual Framework of Freedom of Claiming Right to Education}

Students generally consider themselves insufficient about conceptual framework of freedom of claiming right to education. Only two students consider themselves are sufficient about it. Students reported that they learn conceptual framework of freedom of claiming right to education by their own efforts or their experiences. Half of the students mentioned that right to education was a constitutional right and other half of the students mentioned that they have no information on the legal content of right to education. Most of the students have no information about other legal regulations of right to education except constitutional regulation. Also, three of the students have mentioned that they have superficial information about right to education' legal regulations.

\subsection{Process of Claiming Right}

Most of the students are downtrodden outside of their education life. Three of the students aren't downtrodden outside of their life of education. All of the students are downtrodden in their education life. Half of the students who are downtrodden in education life have done nothing for to claim their right. Five of students who have done something to claim their right have chosen appealing administrative authorities by petition. These students stated that they administrative authorities were not interested enough and they couldn't take a result. Three of petitions were about exam of excuse; one of about transportation to campus and one of about an awareness-raising activity will be held at the university. The three of students who applied administration to claim their right stated that causes of these injustices were arise from attitudes of administrators. They mentioned that administrators were indifferent to demands of students. One of the student bounded causes of injustices to political thoughts. And one of the student bounded causes of injustices to inadequate infrastructure and the financial difficulties of universities'. Students who have done nothing for claiming their rights are generally bounded causes of injustices to physical environment conditions and material shortages. Also these five students think that their schools have a financially insufficient. Two of these five students criticized apathetic and reluctant attitudes of administration in order to overcome the shortcomings.

\subsection{Information of Students' About Remedies}

Most of the students have superficial information about recoursing to the administration. Half of the students mentioned that they have a superficial knowledge about administrative proceedings. These students have mentioned right to petition and right to information. Four of the students mentioned that they have no information about administrative proceedings and only one of the student mentioned that he has information about administrative proceedings. Half of the students mentioned that they have a superficial knowledge about compensation cases. Four of the students mentioned that they have no information about compensation cases. And only one of the student mentioned 
that he has information about compensation cases. Half of the students mentioned that they have a superficial knowledge about criminal cases. Other half of the students mentioned that they have no information about criminal cases. Most of the students have no information about Human Rights Committee. Three of the students have superficial information about Human Rights Committee. Most of the students have no information about Elimination of Discrimination against Women Committee. Only two of the students mentioned that they have information about Elimination of Discrimination against Women Committee. Most of the students have superficial information about European Court of Human Rights. Only three of the students mentioned that they have information about European Court of Human Rights.

\subsection{Obstacles of the Process of Claiming Right}

All of the students stated that government system and political system are obstacles of claiming right process. Nine of the students stated that education system is an obstacle of claiming right process. Students indicated that Universities must have the freedom of organizing their own inner affairs. They said that Universities must be independent to execute their administrative tasks. Therefore, they don't support an education system which covers Universities in centralized management system. Two of the students mentioned that structure of their family is an obstacle of claiming right process. The other two of the students mentioned that their personality is an obstacle of claiming right process. Two of the students mentioned that structure of society is an obstacle of claiming right process.

\section{Discussion and Conclusions}

According to the research findings, it is observed that attitude of claiming right has not occurred among students. Also students' consciousness about claiming right seems to be quite inadequate. Therefore, classes like 'Human Rights' should be included in the training program. These classes will give attitude of claiming right to students and they will develop consciousness about claiming right. Classes like these must have practical activities and drama. These classes would have high reliability and would be convincing by this way. Some students who attended the research were also found suggestions in this direction.

In this study, it appears that the attitude of administrators is an essential obstacle of claiming right. Students indicated that radical changes in the education system should be done to change administrators' attitudes. Therefore, students stated that they must be the subject of university. Universities should take into account the student's request. Perspective of universities should be this way. And Universities should go to some regulations within their structures. Changing the attitude of administrators passes through with a solid appointment and assignment strategy.
An amendment of law is needed about administrators. Administrators of an educational institute must have democratic perspective to create a democratic environment in institution. And also appointments and assignments should be done via merit system.

It's obvious that having high degree of information about fundamental rights and freedoms points a high level of consciousness. One of the traditional problems of Turkish educational system is failure to reflect information to attitudes and behaviors. Researches show that reflection of information to attitudes and behaviors is a problem of education system (Akçay \& Üzüm, 2015). As a solution, concept and methods of education must be more participant, application oriented and attitude developer. A different perception about claiming right would reflect to the attitudes and practice.

According to the research findings, system of government and political system are obstacles of claiming right process. In the shade of these systems, education system wouldn't be as it's supposed to be.

Finally, Higher Education Institutions Student Disciplinary Regulations which seems to be a handicap for freedom of claiming right must be reorganized. Sentences of this regulation which prevents freedom of claiming right should be removed. More moderate arrangements should be made which focuses on students.

\section{REFERENCES}

[1] Akçay, R. Cengiz \& Üzüm, Püren. (2015). Faculty of Education students' Opinions about the Freedom of Claiming Right. Presented at V11. European Conference On Social And Behavioral Sciences, June 11-13, 2015 - Bucharest, Romania Abstract No: 2201.

[2] Balc1, A. (2005). Sosyal Bilimlerde Araştırma. Ankara: Pegema Yayıncilık.

[3] Fraenkel, J. R. \& Wallen, N. E. (2003). How to design and evaluate research in education. New York: McGraw-Hill.

[4] Gay, L. R., Mills, G. E. \& Airasian, P. (2006). Educational research: Competencies for analysis and applications (8th ed.). New Jersey: Pearson Education, Inc., Upper Saddle River.

[5] Gözübüyük Ş. \& Tan, T. (2014). İdari Yargılama Hukuku $\left(7^{\text {th }}\right.$ ed.). Ankara: Turhan.

[6] Kaboğlu, İ. Ö. (1999). Özgürlükler Hukuku: İnsan Haklarının Hukuksal Yapısi (5 ${ }^{\text {th }}$ ed.). İstanbul: Afa.

[7] Kapani, M. (1981). Kamu Hürriyetler (6 $6^{\text {th }}$ ed.). Ankara: Ankara Üniversitesi Hukuk Fakültesi Yayını.

[8] Lincoln, Y. S. \& Guba, E. G. (1985). Naturalistic Inquiry. CA: Sage.

[9] Ovacık, M. (2003). Türkçe-İngilizce Hukuk Sözlüğ̈̈ (5 ${ }^{\text {th }}$ ed.). Ankara: Banka ve Ticaret Hukuku Araştırma Enstitüsü Yayınlar1. 
[10] Özsoy, S. (2004). Eğitim Hakkı: Kendi Dilini Bulamamış Bir Söylem. Ë̌itim Bilim Toplum, Vol. 10, No.5.

[11] Patton, M. Q. (2002). Qualitative research and evaluation methods. Thousand Oaks, CA: Sage.

[12] Sabuncu, Y. (2014). Anayasaya Giriş (16 ${ }^{\text {th }}$ ed.). Ankara: İmaj.

[13] Şafak, A. (2002). Ansiklopedik Hukuk Terimleri Sözlüğü ( $4^{\text {th }}$ ed.). Ankara: Selim.

[14] Tezcan D., Erdem M. R. \& Sancakdar O. (2002). Türkiye'nin Insan Hakları Sorunu. Ankara: Seçkin.

[15] Tezcan, D., Erdem, M. R., Sancakdar, O. \& Önok, R. M. (2010). Insan Haklarl El Kitabı (3 ${ }^{\text {rd }}$ ed.). Ankara: Seçkin.
[16] Toroslu, N. \& Feyzioğlu, M. (2014). Ceza Muhakemesi Hukuku (12. Edition). Ankara: Savaş.

[17] Yıldırım, A. ve Şimşek, H. (2008). Sosyal Bilimlerde Nitel Araştırma Yöntemleri (6 ${ }^{\text {th }}$ ed). Ankara: Seçkin.

[18] Y1lmaz, E. (1996). Hukuk Terimleri Sözlüğü (5 ${ }^{\text {th }}$ Ed). Ankara: Yetkin.

[19] http://www.mevzuat.gov.tr 3071 Law of Using Right to Petition.

[20] http://www.mevzuat.gov.tr 4982 Law of Right to Getting Information

[21] http://www.tbmm.gov.tr/anayasa.htm Constitution of Turkish Republic

i This study presented at 7.th World Conference on Educational Sciences on 5-7 February 2015 in Athens and was published as abstract. 